\title{
A STYLISTIC ANALYSIS OF EDGAR ALLAN POE'S THE BLACK CAT
}

\section{QIAN IIU}

School of Foreign Studies, Jinan University, West Huangpu Avenue, Guangzhou, China

\begin{abstract}
Edgar Allan Poe is indeed one of the most influential writer, critic, poet and editor in American history and very well-known, in the literature world. With his "Gothic" style of writing, The Black Cat is considered as one of his best works. Stylistics is a discipline that studies style by using modern linguistic theories and methodology. Based on the literary stylistic theories, this paper focuses on analyzing The Black Cat from the following aspects: lexical features, syntactical features, rhetorical features and point of view. By doing so, this paper finds that Allan Poe uses these stylistic devices to create the fear and horror of the gothic story. By means of this gothic style in The Black Cat, Poe conveys the idea that the evil is always punished and implies the eternal moral of humanism which is also important nowadays.

KEY WORDS: The Black Cat; Lexical Features; Syntactical Features; Rhetorical Features \& Point of View
\end{abstract}

Received: Oct 23, 2017; Accepted: Nov 13, 2017; Published: Dec 01, 2017; Paper Id.: IJELDEC20178

\section{INTRODUCTION}

Edgar Allan Poe (1809-1849), an American poet, short-story writer, editor and literary critic, has been considered as part of the American Romantic Movement and the crest in the development of the American gothic traditions. Best known for his tales of mystery and the macabre, Poe is recognized as one of the first American practitioners of the short story and is considered as the inventor of the detective-fiction genre. Lowell thinks Poe's style "is highly finished, graceful, and truly classical" (14) and he calls Poe "the master of a classic style" (15). George Bernard Shaw simply says that Poe's tales "are masterpieces of style" (99) and he ranked Poe with Mark Twain as the only two great authors of America in the $19^{\text {th }}$ century. Herbert Marshall McLuhan calls Poe "the master of a prose whose lucidity and resilience are unmistakably owing to a society in which good talk is common" (30). Although he lived a short and tragic life, Edgar Allan Poe remains today one of the most famous writers.

Edgar Allan Poe's short story The Black Cat, first published in the August 19, 1843, issue of the Saturday Evening Post, remains one of his most mystifying and horrifying tales. It is a chilling story recounting the events that precede its narrator's imminent execution. The narrator tells a tale of horror and murder from a prison cell. The story tells the changing process of personality from human to perverse. The author seems to say that human nature is so vulnerable to exterior influences that once it is twisted, the person could commit the most unthinkable evil deeds with abnormal emotional urges without knowing what the urges are. People obsessed with these urges always turn into dual-personality. The evil is always punished in the end.

There have been plenty of researches and reviews by critics and readers of The Black Cat. However, most of the researches concentrate on themes and narrator, and few of them are done on the linguistic features and literary devices, that is, the stylistic features of Edgar Allan Poe's The Black Cat. From the above analysis, this 
paper tries to analyze The Black Cat by means of literary stylistics and finds that Edgar Allan Poe excellently employs stylistic devices like lexis to achieve the gothic horror in The Black Cat. In order to better understand and appreciate the thematic meaning and aesthetic value of The Black Cat, this paper will be carried out to answer the following questions:

- What are the lexical features in The Black Cat?

- What are the syntactical features in The Black Cat?

\section{A STYLISTIC ANALYSIS OF THE BLACK CAT}

Stylistics is a discipline mediating between linguistics and literary criticism. The purpose of stylistic investigation on linguistic form is to reveal its stylistic value. It refers to thematic significances and aesthetic values generated by linguistic form, which convey the author's vision, tone and attitude, embody the mingling or shifting of points of view, add to the affective or emotive force of the massage, contribute to characterization and make fictional reality function more effectively in fictional narrative. According to Leech and Short, "every analysis of style, in our terms, is an attempt to find the artistic principles underlying a writer's choice of language" (74).

The word "gothic" in literary criticism is unfortunately a synonym of the pejorative term- terror. The writing style has even been scorned as a formula, bristled with violence, murder, revenge, rape, incest, or even with presence of ghost, monster or some other supernatural phenomena; the prevailing atmosphere of such fictions is somber, mysterious, horrible and always filled with a sense of suspense. As the most important heir and reformer of the gothic tradition, Poe not only inherited the quintessence of gothic novels, he also deepened the connotation of it. In Poe's works, he vividly presents the terror of death, evil of human nature, perverseness and nothingness.

In Poe's short story The Black Cat, Poe adopts a lot of modifies and long sentences to show a heavy and complicated style. Horror is considered to be an aesthetic effect generated by certain linguistic choices. So this paper tries to analyze how particular linguistic forms can give rise to horror based on lexical features, syntactical features, rhetorical features and point of view.

\section{LEXICAL FEATURES IN THE BLACK CAT}

Lexicology studies the choice of specific lexical items in a text, their distribution in relation to one another, and their meanings. According to Michael Toolan, Word-choice (or lexis, or what used to be called 'diction') is central to whatever is distinctive about a particular literary text. We can define a good style, as "the best words in the best order relative to particular purposes at a particular socio-cultural moment" (Toolan 162).

In The Black Cat, this story is told by the first-person narrator about his murdering his wife and the focus is not on the murdering act but on the psychoanalysis of the protagonist's perverse mental state. Poe tries to describe the mental state between sane and insane. When the murderer committed the crime, he did it cunningly. But the murdering itself was totally unreasonable and crazy. The wife had done nothing to entail this fate, which was caused completely by the perverse psychology of the murderer himself. Perusing this story, this paper finds that Poe makes good use of the adjectives, verbs, nouns, and lexical deviations like capitalization and italic to describe the protagonist's psychology and behavior, which bring readers a feeling of horror.

Firstly, this paper finds that adjectives appear quite frequently and that several adjectives are used before one noun to just modify it through the whole story. These adjectives are mostly related with psychological, emotive or moral 
qualities. To exhibit the protagonist's complicated and confused mind, Poe uses adjectives to achieve the effect. For example, "I grew, day by day, more moody, more irritable, more regardless of the feelings of others" (Poe 101). Here, three adjectives on the narrator's psychology are juxtaposed to describe the process of his transmutation. What is more, "Its evident fondness for me, rather disgusted and annoyed. By slow degrees, these feelings of disgust and annoyance rose into the bitterness of hatred" (Poe 105). In this sentence, the adjectives "disgusted" and "annoyed" are also juxtaposed to describe the narrator's emotion and attitude towards the new black cat. What is more, "disgusted" and "annoyed" have been turned into noun form "disgust" and "annoyance" to enhance this feeling. And to describe the change of protagonist's feelings, the adjectives "bitter" and "hate" are used in their noun forms "to reflect the deepened abhor of the protagonist's feelings. At the climax of The Black Cat, "while, from the sudden, frequent, and ungovernable outbursts of a fury to which I now blindly abandoned myself, my uncomplaining wife, alas! Was the most usual and the most patient of sufferers" (Poe 107). In this sentence, five adjectives are employed to highlight the contrast between the protagonist and his wife. The "fury" was "sudden", "frequent" and "ungovernable," while the wife was "the most usual" and "the most patient" sufferer. This gives a vivid description of the protagonist's perversity which brings him evil deeds towards his kind wife. The use of adjectives contributes to the establishment of gothic features in The Black Cat.

Secondly, the use of verbs in The Black Cat is also conspicuous and of great stylistic significance. The examples are as follows. In the first paragraph, "In their consequences, these events have terrified-have tortured-have destroyed me" (Poe 99). These verbs are juxtaposed and placed in a step-up order to describe the events' horrible effects for the protagonist and show the protagonist's sufferings. When the protagonist committed his first atrocious act, Poe writes, "I took from my waistcoat-pocket a pen-knife, opened it, grasped the poor beast by the throat, and deliberately cut one of its eyes from the socket! I blush, I burn, I shudder, while I pen the damnable atrocity" (Poe 101). In the first sentence, four verbs "took" "opened" "grasped" and "cut" are used to emphasize the quick speed when the protagonist committed the cruel act while no conjunction words are employed among the three verbs. And in the second sentence, three verbs construct the parallel effect to show the vehemence of the protagonist's feelings. At the climax of this story, "Uplifting an axe, and forgetting, in my wrath, the childish dread, which had hitherto stayed personification in my hand, I aimed a blow at the animal" (Poe 107). In this sentence, "uplift" and "aim" are dynamic while "forget" and "stay" are stative. This combined use of dynamic and stative verbs shows that the murderer was out of the control of reason and he was at the verge of craziness. Stopped by his wife from killing the black cat, the protagonist "Goaded, by the interference, into a rage more than demonical, I withdrew my arm from her grasp and buried the axe in her brain" (Poe 108). Here verbs appear short and powerful which shows the extreme madness of the protagonist.

Thirdly, Poe uses different nouns to refer to two black cats which show the protagonist's changing attitude. At the beginning, the protagonist called the first black cat "him", "he", "favorite pet and playmate" (Poe 101). After drinking the alcohol, the protagonist called the black cat "the cat" (Poe 101). When "I" cut one eye out, the protagonist called the cat "poor beast" (Poe 101). When "I" decided to hang the cat, "I" called the cat "unoffending brute" and "it" (Poe 102). The changes of nouns referring to the first black cat show the protagonist's love towards the cat dies away. In the later, when "I" met the second black cat, the protagonist first called it "some black object" and "it" (Poe 104), then "I" called the cat "a great favorite". When "I" found a dislike to the cat arising within me, "I" called the cat "the creature" and "it" (Poe 105). When the cat inspired the protagonist' terror and horror, "I" called the cat "the strange beast" (Poe 106), "the monster" and "the animal" (Poe 107). After the protagonist's evil deeds, he called the cat "the beast", "crafty animal", "detested creature", "my tormentor", "the monster" (Poe 109) to show his hatred feeling toward the cat. In the end, when 
the police found what the protagonist had done, "I" called the cat "hideous beast" to show my fury toward the cat. All these nouns referring to the cats display the protagonist's changing mind and show the readers how the protagonist committed the crime gradually. This kind of description of the cat also shows the protagonist is profoundly superstitious and the perverseness that the protagonist cannot control in the story. What is more, the protagonist is terrified not of time and death but of "demonic" black cats, damnation, the Devil, and an angry, punishing God, which are of course gothic features. Here are some words in The Black Cat contributing to the horror and mystery of the story because of supernatural things: “witches” (Poe 100), “soul” "fiend” “demon" (Poe 101), “deadly sin” "my immortal soul” "High God” (Poe 107), "guilt” (Poe 109), “Arch-Fiend” (Poe 110), "hell” “damnation” (Poe 112).

Fourthly, Poe uses the deviation of words like capitalization and italic to show his emphasis of changing process of the protagonist's psychology and create a mystical atmosphere of the story. For example, perverseness in "the spirit of PERVERSENESS" (Poe 102) is capitalized to emphasize the mystical power of perverseness that changes the protagonist. “...mercy of the Most merciful and Most Terrible God" (Poe 103), here "Most" and "Terrible" are capitalized to imply that the deadly sin committed by the protagonist is so evil that it is hard to forgive. The sentence "of a ghastly thing- of the GALLOWS! - oh, mournful and terrible engine of Horror and of Crime- of Agony and of Death" (Poe 107) has five words to be capitalized. "GALLOWS" used to show the protagonist's shock and fear. The second cat's appearance is strange and comes to avenge the cruelty of the narrator, which is full of gothic feature of strangeness. "Horror" "Crime" "Agony" and "Death" are used to imply that the protagonist's dread of the second black cat and create a gothic suspense of the story. Suspense itself harbors elements of terror. The use of suspense would enhance the feeling of terror, stimulates readers' fear and desire, and at the same time ensure the existence of distance. What is more, "we had birds, gold fish, a fine dog, rabbits, and a small monkey, and a cat" (Poe 100), here "a cat" is in the italic form to show the uniqueness and strangeness of the cat and to enhance the impression of the black cat, which has a pushing forward effect of the whole story. And in the sentence "It was this unfathomable longing of the soul to vex itself" (Poe 102), here "vex itself" is italic to show that the protagonist is suffering from the perverseness so that he has very complex psychology to do the evil deeds. And then Poe uses three italic "because" to show the protagonist's remorse and bitterness in his heart, “... hung it because I knew that it had loved me, and because I felt it had given me no reason of offense, -hung it because I knew that in so doing I was committing a sin..." (Poe 103). These italic words show how unimaginable and crazy the protagonist is to hang the first black cat and they also show the perverseness is so powerful that "I" cannot control "myself."

From the above analysis, this paper finds that Poe's use of words helps him to create the atmosphere and characters of extreme horror in The Black Cat.

\section{SYNTACTICAL FEATURES IN THE BLACK CAT}

Lexical choice is a basis aspect to achieve literary purpose. However, words make up sentences which gather to form a text, so syntax also contributes a great deal to literary significance. Writers have to decide what kind of syntactic structures should be used, simple or complex, loose or periodic, etc. Poe is a great literary critic and his theories for the short story are exemplified in his Review of Hawthorne's Twice-Told Tales (1848) and The Philosophy of Composition (1846). Poe held that the short story must be of such length as to be read "at one sitting" (brevity), therefore ensuring the "totality of impression". The very first sentence is intended to help to bring out the "single effect" of the story. No word should be used which without contributing to the "pre-established" design of the work (compression). After reading The Black Cat, this paper finds that Poe tries to achieve the single effect in his story so that he compress a lot of 
information in one sentence. So complex sentence could be found easily in his story.

The sentence "Uplifting an axe, and forgetting, in my wrath, the childish dread which had hitherto stayed my hand, I aimed a blow at the animal which, of course, would have proved instantly fatal had it descended as I wished" (Poe 107) is a very complex sentence as far as the number of clauses that it contains, hence the number of ideas that it expresses (Malik 30). From this sentence, this paper finds that, the non-finite clause "Uplifting an axe" expresses a very important turning point in the story, which leads later on to the brutal action of murder and remorse finally. Another subordinate clause is 'forgetting the childish dread' which also followed by another dependent clause which modifies it which had hitherto stayed me hand". "Which, of course, would have proved instantly fatal", which is also concerned with describing the brutal event, around which the plot revolves. Poe uses the subordinate clauses, to depict more details and arise more interpretations in the whole story. At the same time, the main clause is foregrounded "I aimed a blow at the animal" to show the violence of the protagonist. In The Black Cat, the protagonist was living in a typical gothic building. The cellar in which he hid his wife's body was pervaded a sense of horror, because it was well adapt for his vicious purpose, that is, walling his wife's body. "Its walls were loosely constructed, and had lately been plastered throughout with a rough plaster, which the dampness of the atmosphere had prevented from hardening." "Moreover, in one of the walls was a projection, caused by a false chimney, or fireplace, that had been filled up and made to resemble the rest of the cellar." (Poe 108) Therefore, "I made no doubt that I could readily displace the bricks at this point, insert the corpse, and wall the whole up as before, so that no eye could detect anything suspicious." (Poe 108) Such complex sentences contains scene and events that produced the atmosphere of terror did greatly contribute to the gothic feature of this tale. Furthermore, in these sentences "I took from my waistcoat-pocket a pen-knife, opened it, grasped the poor beast by the throat, and deliberately cut one of its eyes from the socket! I blush, I burn, I shudder, while I pen the damnable atrocity" (Poe 101), to quicken the pace of the sentence and deliver the murderer's vehement emotion, no conjunctions are used to join the clauses. The verbs "took" "opened" "garsped" and "cut" are directly used to describe the continuous acts happened instantly. And between the two sentences, there is either no conjunctions to block the strong feelings, several verbs appear again. In the second sentence, the main clause 'I blush, I burn, I shudder', which is the dreadful narrator's inner agony and this gives more depicting to the main character of the novel. What is more, Poe also uses complex sentences to deliver the conflicting feelings. For example,

One morning, in cool blood, I slipped a noose about its neck and hung it to the limb of a tree; --hung it with the tears streaming from my eyes, and with the bitterest remorse at my heart;--hung it because I knew that it had loved me, and because I felt it had given me no reason of offense; --hung it because I knew that in so doing I was committing a sin--a deadly sin that would so jeopardize my immortal soul as to place it--if such a thing were possible--even beyond the reach of the infinite mercy of the Most Merciful and Most Terrible God (Poe 103).

In the above sentence, prepositional phrases "with the tears streaming from my eyes" and "with the bitterest remorse at my heart" are used to depict the conflicting emotion in the protagonist's mind. And to explain the motive, three clauses are employed "because...because...because..." to show the protagonist's morbid psychology. According to Badenhausen, the horror in Poe's tale originates not from the descriptions of murder or decomposing corpses, but from the reader's realization that the narrator is aggressively arguing his case and that given a last opportunity to humanize the self through a confrontation with death, he still fees in its face (498). Poe employs complex sentences in The Black Cat to show the complex mind of the protagonist and contains scene and events that produced the atmosphere of terror did greatly 
contribute to the gothic feature of this tale.

\section{CONCLUSIONS}

Edgar Allen Poe is indeed a great writer and he has been considered as one of the earliest American practitioners of the short story. His short stories are everlastingly charming and enduring owes much to his special gothic style. Gothicism is strongly characterized by its distinctive feature of "dark" both in plot and theme: in plot-knitting, it romances densely on ferocity and devilishness; thematically, it aims at profoundly probing into the human nature of wickedness, especially on ethics through the unveiling of the gloomy side and malice in society, politics, religion, morality as well as humanity. Poe here employs a variety of stylistic devices in creating his story The Black Cat. By analyzing the lexical features and the syntactical features in The Black Cat, this paper finds that Poe uses stylistic devices to create a gothic atmosphere and to show the dilemma and madness of the protagonist, which profoundly probes into the human nature. With all stylistic devices contributing to gothic feature in this story, Poe tries to shock all readers by the power of perverseness and to convey that the evil is always punished at last.

\section{REFERENCES}

1. Badenhausen, R. (1992). Fear and Trembling in Literature of the Fantastic: Edgar Allan Poe's "The Black Cat”. Studies in Short Fiction(4):487-498.

2. Short, M. H. \& Leech, G. N. (2001). Style in Fiction: A Linguistic Introduction to English Fictional Prose. Beijing: Foreign Language Teaching and Research Press, 2001.

3. Lowell, J. R. (1999). “Edgar Allan Poe.” The Recognition of Edgar Allan Poe: Selected Criticism Since 1829, edited by Eric W. Carlson and Ann Arbor, MI: University of Michigan Press, pp. 5-16.

4. Malik, M. (2017). “A Stylistic Study of the Use of Complex Sentences in Poe's The Black Cat.” IOSR Journal of Humanities and Social Science: $29-31$.

5. Mcluhan, H. M.(1994). “Edgar Poe’s Tradition.” Sewanee Review. 52: 24-33.

6. Poe, E. A. (2010). Tales of Mystery and Imagination. Beijing: Foreign Language Teaching and Research Press..

7. Shaw, G. B. (1996). “Edgar Allan Poe.” The Recognition of Edgar Allan Poe: Selected Criticism Since 1829, edited by Eric W. Carlson and Ann Arbor, MI: University of Michigan Press, pp.95-100.

8. Toolan, M. J.(2008). Language in Literature: An Introduction to Stylistics. Beijing: Foreign Language Teaching and Research Press. 